\title{
INSTITUTE AFFAIRS
}

\author{
Canadian Institute of Forestry \\ Institut Forestier du Canada \\ Suite 606, 151 Slater St. \\ Ottawa, Ontario, Canada \\ $\mathrm{K} 1 \mathrm{P} 5 \mathrm{H} 3$ \\ Tel. (613) 234-2242 \\ Fax. (613) 234-6181 \\ E-mail 103741.553@compuserve.com
}

President/Président $-\mathrm{S}$. Tolnai 1st Vice-President/1er vice-président J.E. Barker

2nd Vice-President/2ème vice-président R. Roberts

Past President/Président sortant H. Oldham

Executive Director/directrice executive R. Comeau

\section{Directors/directeurs}

F. Pinto, Algonquin, J. Kavanagh, Cariboo, K. Dufresne, Cariboo-Chilcotin, G. Stone, Centra Ontario, D. MacArthur, Champlain, J. Harrison, Lake of the Woods, B. Yatowski, Manitoba, G. Van Raalte, Maritime, M. Churchill, Newfoundland, R. Galloway, Northem Ontario N. Carl, Northwestern Ontario, J. MacLellan, Nova Scotia, R. Willis, Okanagan, R. Doucet, Orleans, J.-L. Wallace, Ottawa Valley, S. Michalsky, Rocky Mountain, M. McLaughlin, Saskatchewan, R. Braam, Skeena, K. Elliot, Southern Ontario, D. Carson, Vancouver Island.

Section Chairs/president du section A. Morneault, Algonquin, P. Forsythe, Cariboo, Keith Dufresne, Cariboo-Chilcotin, G. Stone, Central Ontario, R. Dixon, Champlain, J. Harrison, Lake of the Woods, J. Delaney, Manitoba, R. O'Connell, Maritime, M. Churchill, Newfoundland, Rob Galloway, Northem Ontario, R. Klein, Northwestern Ontario, C. Bowers, Nova Scotia, B. Jennejohn, Okanagan, J.P. Dansereau, Orleans, K. Forbes, Ottawa Valley, Mike Dietsch, Pacific, C. Quintilio, Rocky Mountain, M. McLaughlin, Saskatchewan, Bill Camenzind, Skeena, K. Elliot, Southern Ontario, D. Lloyd, Vancouver, D. Carson, Vancouver Island.

Forest Science and

Technology Board

Comité des sciences et technologies forestières

Peter Marshall, Chair/président, Pierre Bemier, Past Chair/président sortant, R. Comeau, Secretary/secrétaire, Glen Blouin, For. educ., D. Brand, Silv. and tree imp., Victor Brunette, Private for., J. Volney, For. pest management, J. Hall, International for., A. Harestad, Wildlife and fish hab., G. Huntley, Urban for., V. LeMay, For. measurement, T. Williamson, For. econ. and policy, E. McGurk, For. hydrology, A. Sinclair, For. harvesting.

\section{The Executive Director Reports}

Our visit to Members of Parliament during National Forest Week was interesting and successful for the most part. We were able to meet with many of the members of the Standing Committee on Natural Resources, the new Parliamentary Secretary for Natural Resources - Marlene Cowling and senior CFS policy advisor Dan Paskowski. Our main messages were (1) who is CIF/IFC?; (2) the importance of a federal role in forestry; (3) what the CIF/IFC can do for you. The messages that we received back were varied.

The Liberals felt that if the CIF/IFC wanted to help with respect to the federal role in forestry, it would be a good idea to talk to the Provinces. It was expressed that the Provinces are requesting the federal role be reduced

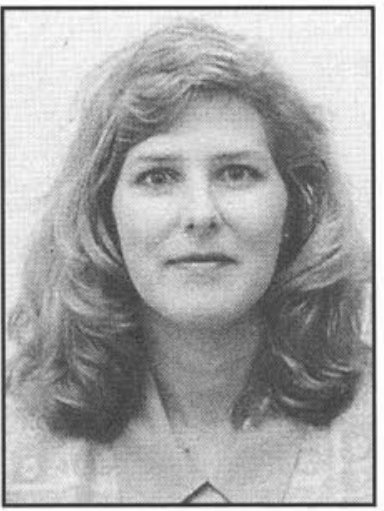
(Charlottetown Accord). We asked the Liberals what they thought was meant by the recent federal government speech from the throne:

The government is prepared to withdraw from its functions in such areas as labour market training, forestry, mining and recreation, that are more appropriately the responsibility of others, including provincial governments, local authorities or the private sector... .

Most of the Liberals responded that the work was already in progress as later stated by the Federal NRC Minister Anne McLellan in the house on 9 May in response questioning by Mr. Gilles Duceppe (PQ). She stated "This promise is about sorting out responsibilities. I assure the hon. member those areas that we continue to be involved with in forestry are within federal jurisdiction, for example the $25 \%$ of forests on federal crown lands, the First Nations and their lands. Forestry is an important aspect of their economic self-sufficiency." CIF/IFC committed to writing to the Provinces emphasizing the importance of a Federal Role in Forestry.

The Minister's staff mentioned that the Natural Resources Standing Committee would be focusing their attention on Rural areas and CIF/IFC offered support on the ground and at hearings.

We were also able to meet with several members of the Reform Party. They questioned the need for the federal government in several areas of forestry, and requested from the CIF/IFC a detailed listing in half a page the areas where CIF/IFC felt the federal government should be focusing their efforts in forestry. Following this meeting, Mr. Darrel Stinson sent our office a letter requesting further information on the federal government involvement in forestry issues. (Mr. Stinson's letter is reprinted in the Letters section of this edition of The Forestry Chronicle. A response from members directly to Mr. Stinson to our office is welcome.)

We also met with the Harry Bombay, Executive Director, National Aboriginal Forestry Association. Mr. Bombay provided the Executive Committee with information on NAFA, regional affiliates and membership structure as well as their national activities and recent involvement with Indian Affairs and land claim issues. He highlighted the recently announced First Nations Forestry Program which is a three-year commitment and \$6 million to business development and partnership with industry and the First Nations. NAFA has been involved with the regulatory process to deal with lands and establishing bylaws and forest management issues and are working on revising the Indian Act and the Indian Timber Regulations which are out of date. NAFA has also been giving workshops on how the FSC and CSA processes will effect Indian lands. The CIF/IFC Executive offered our cooperation on activities wherever possible. NAFA will continue to submit an article to The Chronicle on a regular basis. 